\title{
TINGKAT PENDIDIKAN, LITERASI KEUANGAN, DAN PERENCANAAN KEUANGAN TERHADAP PERILAKU KEUANGAN UMKM DI SURAKARTA
}

\author{
Ari Susanti $^{\bowtie}$, Ismunawan, Pardi, Elia Ardyan \\ Sekolah Tinggi Ilmu Ekonomi Surakarta \\ e-mail: santihesa@yahoo.com
}

\begin{abstract}
This study aims to determine the level of education, financial literacy, and financial planning in Small and Medium Enterprises in Surakarta and its influence on financial behavior. The sample of research is 115 MSMEs residing in Surakarta. Data analysis using multiple linear analysis. The results showed that the level of education, financial literacy, and financial planning have a positive and significant impact on the financial behavior of MSMEs. Its managerial implications are needed to foster a healthy understanding of financial behavior in MSMEs by attending various training on finance and management of small and medium enterprises.
\end{abstract}

Keywords: education level, financial literacy, financial behavior, financial planning, MSME's

\begin{abstract}
Abstrak
Penelitian ini bertujuan untuk mengetahui tentang tingkat pendidikan, literasi keuangan, dan perencanaan keuangan pada Usaha Kecil dan Menengah di Surakarta dan pengaruhnya terhadap perilaku keuangan. Sampel penelitian berjumlah 115 UMKM yang berada di Surakarta. Analisis data menggunakan analisis linier berganda. Hasil penelitian menunjukkan bahwa tingkat pendidikan, literasi keuangan, dan perencanaan keuangan berpengaruh positif dan signifikan terhadap perilaku keuangan UMKM. Implikasi manajerialnya diperlukan usaha untuk menumbuhkan pemahaman perilaku keuangan yang sehat pada UMKM dengan mengikuti berbagai pelatihan tentang keuangan dan manajemen usaha kecil dan menengah.
\end{abstract}

Kata kunci: tingkat pendidikan, literasi keuangan, perencanaan keuangan, perilaku keuangan, UMKM

\section{PENDAHULUAN}

Usaha Mikro Kecil dan Menengah (UMKM) memiliki peranan penting dalam menciptakan lapangan kerja, meningkatkan kesejahteraan rakyat dan memeratakan pendapatan, oleh sebab itu diperlukan dukungan dari seluruh pihak untuk pengembangan UMKM. Pemantauan terhadap UMKM yang sedang berkembang dapat dilakukan dengan adanya laporan keuangan yang dibuat karena kebanyakan UMKMbelummemahamipentingnyalaporan keuangan yang akan berdampak positif untuk kemajuan usahanya. Pengembangan literasi 
keuangan/finansial akan mempengaruhi kegiatan UMKM terutama dalam hal pendanaan, baik di bagian produksi maupun bagian pemasaran karena UMKM yang tidak memiliki literasi keuangan akan terkendala dalam hal pengajuan peminjaman dari perbankan.

Literasi keuangan telah diakui sangat penting bagi individu, bisnis, dan masyarakat secara keseluruhan. Konsumen yang melek finansial dapat membuat keputusan yang lebih tepat dan menuntut layanan berkualitas tinggi. Melek finansial adalah salah satu faktor utama yang mempengaruhi tingkat kelangsungan hidup dan prospek pertumbuhan start up perusahaan (Lennox, 2014). Berdasarkan laporan pembangunan keuangan global pada tahun 2014 Bank Dunia, usaha kecil dan menengah, khususnya di pasar negara berkembang, menghadapi kendala pembiayaan yang signifikan, dan berpotensi pertumbuhan dan inovasi yang negatif. Literasi keuangan adalah alat yang paling efektif untuk mendorong pertumbuhan keuangan bagi rumah tangga dan bisnis (ACCA, 2014).

Perpaduan antara kesadaran, pengetahuan, ketrampilan, sikap, dan perilaku dalam membuat keputusan keuangan bisa dianggap merupakan upaya masyarakat yang melek finansial, pelaku usaha yang melek finansial diharapkan akan mampu membuat keputusan keuangan yang sehat yang pada tujuannya adalah mencapai keuangan individu yang sejahtera (Atkinson dan Messy, 2012). Peningkatan tingkat melek finansial di usaha kecil menengah merupakan hal yang penting untuk pemantuan kegiatan usahanya, terutama pemahaman tentang perkembangan keuangan, bagaimana jangkauan, akses keuangan, aksestabilitas, produk dan layanan keuangan yang ada (Beckett et al., 1998; Marcolin dan Abraham, 2006). Salah satu tujuan usaha kecil menengah dalam memahami keuangan adalah agar keberlangsungan dan keberlanjutan usahanya tetap berjalan dengan lancar. Selain itu kesempatan untuk bekerja sama dengan pihak eksternal untuk peminjaman dan pengajuan kredit akan menjadi lebih mudah (Roberts and Jones, 2001; Lusardi et al., 2010).

Sudah saatnya UMKM untuk mulai memikirkan cara pengelolaan keuangan yang tepat, karena literasi keuangan yang baik akan mampu meningkatkan pendapatan. Pengelolaan keuangan yang tepat yang tentunya ditunjang oleh literasi keuangan yang baik yang mampu meningkatkan taraf kehidupan dan tingkat penghasilan. Beberapa penelitian menunjukkan bahwa literasi keuangan yang mencukupi akan memberikan pengaruh positif terhadap perilaku keuangan seseorang (Robb dan James, 2009).

Memahami faktor-faktor yang terkait dengan literasi keuangan salah satunya melalui pendidikan. Pengalaman pelaku dalam mengelola keuangan merupakan faktor penting yang terkait dengan literasi keuangan dan kinerja pelunasan. Beberapa lembaga pendidikan memberikan pendidikan untuk memberi pemahaman tentang literasi keuangan, pada angkatan muda dan para perilaku bisnis. Pengetahuan yang didapat dari pendidikan yang diikuti memberi pemahaman untuk meningkatkan literasi keuangan, terutama di antara generasi muda (Gerardi et al., 2010). Agarwal, et al. (2009) melakukan penelitian di India tentang perilaku literasi keuangan dan perencanaan keuangan berdasarkan sebuah program penasehat keuangan. Penelitian ini didukung oleh beberapa indikator yaitu perilaku investasi, pilihan kewajiban, toleransi risiko, dan penggunaan asuransi.

Permasalahan yang dihadapi UMKM khususnya usaha batik di Surakarta adalah tingkat pendidikan pemilik yang rendah sehingga literasi keuangan dan perencanaan dalam pengelolaan keuangan belum menjadi acuan utama dalam pengambilan keputusan keuangan. Untuk itu penelitian ini 
bertujuan untuk menguji literasi keuangan dan perencanaan keuangan UMKM batik di Surakarta. Kombinasi antara kesadaran, pengetahuan, sikap dan perilaku keterampilan dalam membuat keputusan keuangan dapat dianggap sebagai usaha masyarakat dimana pelaku bisnis memiliki literasi keuangan untuk mampu menciptakan keputusan keuangan yang sehat yang pada akhirnya bertujuan untuk mencapai perkembangan usahanya.

\section{TINJAUAN PUSTAKA}

\section{Tingkat Pendidikan}

Tingkat pendidikan sangat penting untuk mendukung literasi keuangan agar pelaku membentuk perilaku yang melek finansial. Konsep dan instrument keuangan untuk membuat keputusan keuangan yang tepat sangat tergantung pada tingkat pendidikan seseorang. Hal ini terkait dengan kebijakan pembuatan keputusan yang tepat. Berdasarkan literatur yang berkembang OECD (2014), Agarwal, Driscoll, Gabaix, and Laibson (2008 and 2009), Agarwal, Amromin, Ben-David, Chomsisengphet and Evanoff (2014, 2011, 2010), Lusardi (2004), Lusardi and Mitchell (2007a, 2007b, 2014), Lusardi, Mitchell and Curto (2009), and Mitchell (1988) telah mengevaluasi kondisi literasi keuangan dan efektivitas pendidikan keuangan dan program yang ditujukan untuk memperbaiki pengambilan keputusan finansial.

Pendidikan keuangan sangat berpengaruh pada literasi keuangan hal ini telah dilakukan oleh beberapa penelitian (Sabri, 2011), yang menghasilkan bahwa pendidikan yang diperoleh dari perguruan tinggi akan pembentukan sikap, pengetahuan dan perilaku keuangan. Penelitian yang lain seperti disampaikan oleh Widayati (2012) bahwa aspek kognitif dan aspek sikap memiliki hubungan antara pembelajaran di perguruan tinggi dengan tingkat literasi
keuangan.Pendidikan diukur melalui aspek pendidikan formal yang diperoleh dari pelaku usaha di antaranya adalah pendidikan akhir yang ditempuh.

Menurut Sikula (2011) tingkat pendidikan adalah suatu proses jangka panjang yang menggunakan prosedur sistematis dan terorganisir, yang mana tenaga kerja manajerial mempelajari pengetahuan konseptual dan teoritis untuk tujuan-tujuan umum.

\section{Literasi Keuangan}

Kompetensi seseorang untuk pengelolaan keuangan merupakan keahlian dan kemampuan yang terbentuk untuk memanfaatkan sumber daya dalam pencapaian suatu tujuan. Dimensi yang tidak dapat terpisahkan dari literasi keuangan adalah pengetahuan finansial seseorang (Huston, 2010). Beberapa pendapat lain tentang indikator yang mempengaruhi literasi keuangan adalah penganggaran, tabungan, pinjaman, dan investasi (Remund, 2010) menyimpulkan terdapat empat indikator yang paling umum mempengaruhi literasi keuangan. Hal-hal yang berhubungan dengan literasi keuangan adalah bagaimana pengelolaan pendapatan, pengelolaan keuangan, berinvestasi, pinjaman atau kredit serta pengelolaan tabungan. Literasi keuangan tidak hanya melibatkan pengetahuan dan kemampuan untuk menangani masalah keuangan, tetapi juga atribut non kognitif (PISA, 2012).

Sikap merupakan unsur penting dalam literasi keuangan. Sikap keuangan diartikan sebagai karakteristik psikologis seseorang yang berkaitan dengan masalah keuangan pribadi (Gutter, 2008). Sikap keuangan seperti sikap terbuka terhadap informasi, menilai pentingnya mengelola keuangan, tidak impulsif dalam konsumsi, orientasi ke masa depan, dan tanggung jawab. Chen dan Volpe (1998) mengartikan literasi 
keuangan sebagai kemampuan mengelola keuangan, menurut Lusardi \& Mitchell (2007) literasi keuangan dapat diartikan sebagai pengetahuan keuangan, dengan tujuan mencapai kesejahteraan. Hal ini dapat dimaknai bahwa persiapan perlu dilakukan untuk menyongsong globalisasi (prepare your self), dan lebih spesifiknya yaitu globalisasi dalam bidang keuangan.

\section{Perencanaan Keuangan}

Perencanaan keuangan merupakan proses dimana seseorang akan memenuhi kebutuhan hidup sebagai tujuan keuangan melalui suatu implementasi keuangan baik secara komprehensif sehingga mampu menunjukkan keuangan seseorang. Menurut FPSB (2007) perencanaan keuangan adalah tujuan hidup seseorang yang dilakukan melalui sebuah perencanaan keuangan yang disusun sehingga terbentuk tujuan jangka pendek dan jangka panjang. Perencanaan keuangan dapat terbentuk mulai dari pendapatan, pengeluaran, tabungan, investasi, perencanaan pendidikan anak, pension, dan jaminan hari tua. Untuk dapat menyusun sebuah perencanaan keuangan diharapkan usaha kecil menengah mampu mengerti tentang perencanaan keangan tersebut. Literasi keuangan merupakan pengetahuan mengenai konsep-konsep keuangan (Lusardi, 2009). Personal literasi keuangan mencakup pengetahuan dasar mengenai keuangan pribadi (basic personal finance), pengetahuan mengenai manajemen uang (cash management), pengetahuan mengenai kredit dan utang, pengetahuan mengenai tabungan dan investasi, serta pengetahuan mengenai risiko.

Literasi keuangan, pentingnya, mengukur isu, pelaksanaan program pendidikan keuangan, dan topik terkait sering dibahas di lingkungan akademik dan publik. Tingkat melek finansial yang tinggi membuat kontribusi besar terhadap kesejahteraan finansial individu, karena individu yang melek finansial lebih cenderung untuk merencanakan pensiun (Almenberg \& Save-Soderbergh, 2011), lebih cenderung berpartisipasi di pasar keuangan dan berkinerja lebih baik pada pilihan portofolio mereka (Van Rooij, Lusardi \& Alessie, 2011) dan lebih cenderung menumpuk lebih tinggi jumlah kekayaan (Lusardi, et al., 2011). Pada gilirannya "kurangnya melek finansial adalah salah satu faktor yang berkontribusi untuk keputusan keuangan yang tidak tepat dan bahwa keputusan ini dapat, pada gilirannya, memiliki tumpahan negatif yang luar biasa" (OECD, 2012).

\section{Perilaku Keuangan}

Financial behavior berhubungan denganbagaimana seseorangmemperlakukan, mengelola, dan menggunakan sumber daya keuangan yang ada padanya. Individu yang memiliki financial behavior yang bertanggung jawab cenderung efektif dalam penggunaan uang yang dimilikinya, seperti membuat anggaran, menghemat uang dan mengontrol belanja, berinvestasi, serta membayar kewajiban tepat waktu.

Perilaku merupakan suatu cara bertindak terhadap sesuatu yang terbentuk melalui individu. Perilaku keuangan individu merupakan sikap yang terbentuk dimana seseorang mampu mempertimbangkan dan merencanakan bagaimana mendapatkan anggaran sehingga mampu menabung, menerima risiko keuangan, dan membuat kesesuaian antara kebutuhan dan anggaran yang dibutuhkan untuk keberlanjutan usahanya. Perilaku keuangan pribadi adalah cara dimana individu mengelola sumber dana (uang) untuk digunakan sebagai keputusan penggunaan dana, penentuan sumber dana, serta keputusan untuk perencanaan pensiun (Gitman, 2002). Melek finansial dapat memiliki implikasi penting bagi perilaku finansial, misalnya 
orang dengan tingkat melek finansial yang rendah lebih cenderung memiliki masalah dengan hutang (Lusardi \& Tufano, 2009), cenderung tidak berpartisipasi di pasar saham (Rooij, Lusardi, \& Alessie, 2007), cenderung memilih reksadana dengan biaya yang lebih rendah, cenderung mengumpulkan kekayaan dan mengelola kekayaan tidak secara efektif dan cenderung tidak merencanakan untuk masa pensiun (Lusardi \& Mitchell, 2006). Melek finansial adalah komponen penting bagi pengambilan keputusan keuangan. Sedangkan Olson (2001) memberikan perspektif perilaku keuangan dari proses pengambilan keputusan sebagai berikut:

1. Preferensi pengambil keputusan keuangan

2. Pengambil keputusan keuangan yang adaptif berarti bahwa sifat keputusan dan lingkungan di mana itu membuat pengaruh jenis proses yang digunakan

3. Pengambil keputusan keuangan secara neurologis cenderung untuk menggabungkan mempengaruhi (emosi) ke dalam proses pengambilan keputusan.
Perilaku keuangan itu sendiri juga berasal dari ekonomi neoklasik, homo economicus adalah model perilaku ekonomi manusia yang sederhana mengasumsikan bahwa prinsip-prinsip kepentingan pribadi sempurna, rasionalitas yang sempurna, dan informasi yang sempurna mengatur keputusan ekonomi individu (Pompian, 2006).

\section{Hipotesis}

Berdasarkan kajian teori di atas, maka hipotesis dan model penelitian empiris dalam penelitian ini adalah sebagai berikut:

$\mathrm{H}_{1}$ : Tingkat pendidikan berpengaruh positif dan signifikan terhadap perilaku keuangan UMKM

$\mathrm{H}_{2}$ : Literasi keuangan berpengaruh positif dan signifikan terhadap perilaku keuangan UMKM

$\mathrm{H}_{3}$ : Perencanaan keuangan berpengaruh positif dan signifikan terhadap perilaku UMKM

\section{Kerangka Pemikiran Penelitian}

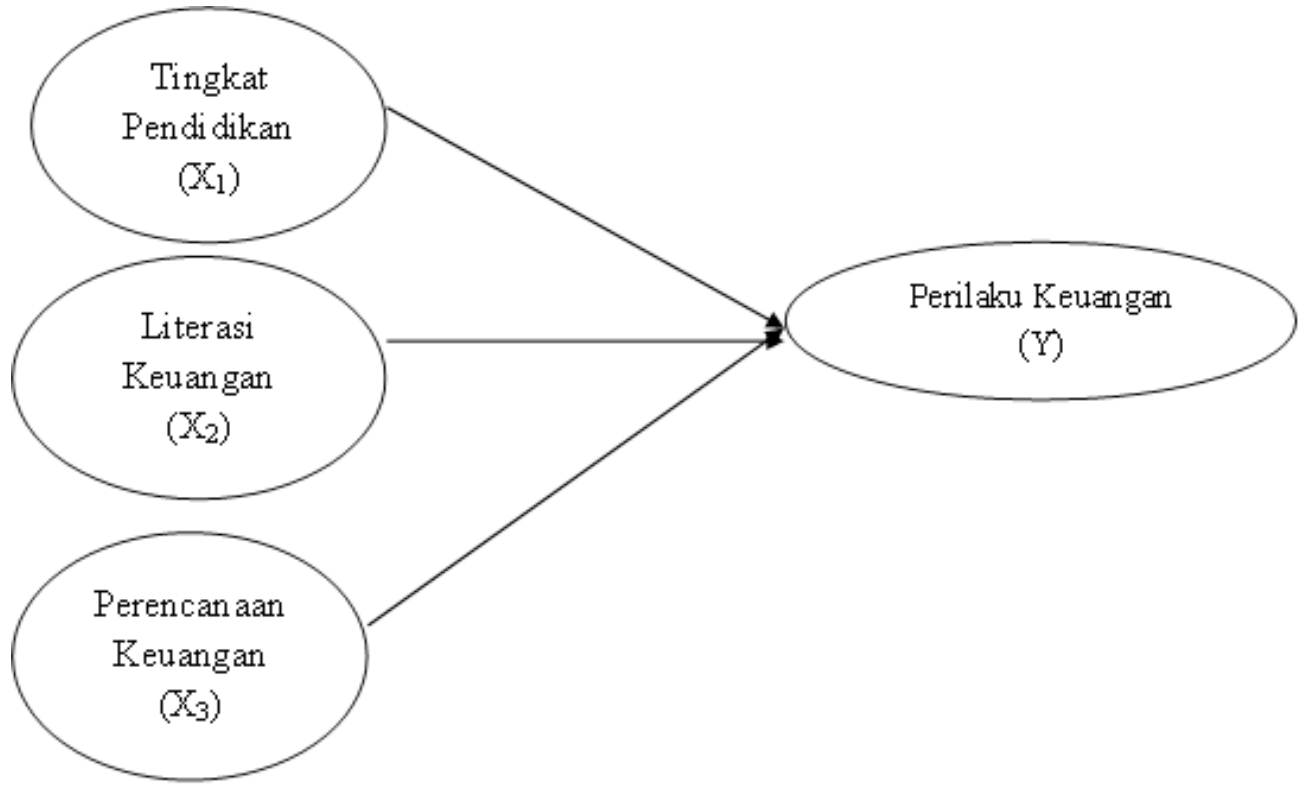

Gambar 1. Model Penelitian Empiris 


\section{METODE PENELITIAN}

Pendekatan yang digunakan dalam penelitian ini adalah pendekatan kuantitatif. Alasan peneliti menggunakan pendekatan kuantitatif karena peneliti bermaksud untuk menghilangkan subjektifitas dalam penelitian. Populasi dalam penelitian ini adalah 115 UMKM batik yang berada di Surakarta. Kriteria pengambilan sampel adalah UMKM yang telah beroperasi minimal 5 tahun. Tehnik pengambilan sampelnya adalah metode sensus.

Analisis data dilakukan dengan analisis regresi linier berganda. Sebelum uji hipotesis, terlebih dahulu dilakukan uji validitas dan reliabilitas, dilanjutkan dengan uji asumsi klasik yaitu uji multikolinieritas, uji autokorelasi, dan uji normalitas.

Berikut adalah definisi operasional penelitian ini.

\section{HASIL DAN PEMBAHASAN}

Berdasarkan jenis kelamin responden penelitian ini adalah UMKM yang pemiliknya perempuan sebanyak 80 orang $(70 \%)$ dan laki-laki sebanyak 35 orang (30\%). Uji validitas dilakukan dengan menggunakan korelasi Pearson. Hasil pengujian validitas pada seluruh butir pernyataan menunjukkan nilai signifikansi 0,00 atau lebih kecil dari 0,05. Dengan demikian seluruh butir pernyataan dinyatakan valid.

Uji reliabilitas menggunakan cronbach alpha. Nilai cronbach alpha pada tiap-tiap variabel adalah 0,816 (Tingkat Pendidikan); 0,726 (Literasi Keuangan); 0,734 (Perencanaan Keuangan); dan 0,775 (Perilaku Keuangan). Semua nilai lebih besar dari 0,60, maka dapat disimpulkan bahwa seluruh variabel penelitian reliabel karena cronbach alpha lebih besar dari nilai yang dipersyaratkan $(0,60)$.

Uji Asumsi Klasik yang dilakukan dalam penelitian ini menggunakan uji multikolinearitas, uji autokorelasi dan uji normalitas. Uji multikolinieritas menggunakan nilai VIF (Varian Infloating Factor). Nilai VIF dalam penelitian ini memiliki nilai $\leq 10$ (Tingkat pendidikan $=1,014 ;$ Literasi Keuangan $=1,016$; Perencanaan Keuangan $=1,005$ ) maka tidak terjadi multikolinearitas. Uji autokorelasi menggunakan nilai Durbin Watson dengan hasil sebesar 1.644 nilai ini berada antara 1,5 sampai 2,5, maka data tidak mengalami autokorelasi. Uji normalitas menggunakan One-Sample Kolmogorov-Smirnov Test dimana nilai Asymp. Sig. (2-tailed) adalah sebesar 0,984. Data dikatakan normal apabila nilai Asymp. Sig. (2-tailed) di atas 0,05, dengan demikian data dalam penelitian ini adalah normal. 
Tabel 1. Definisi Operasional

\begin{tabular}{|c|c|c|c|c|}
\hline VARIABEL & DEFINISI & DIMENSI & PENGUKURAN & SUMBER \\
\hline $\begin{array}{c}\text { Tingkat } \\
\text { Pendidikan }\end{array}$ & $\begin{array}{l}\text { Keahlian teoritis, } \\
\text { konseptual dan } \\
\text { moral yang dimil- } \\
\text { iki. }\end{array}$ & $\begin{array}{l}\text { 1. Latar Belakang pendidikan sesuai. } \\
\text { 2. Kemampuan menganalisis } \\
\text { pekerjaan sesuai dengan latar } \\
\text { pendidikan. } \\
\text { 3. Usaha yang dimiliki sesuai dengan } \\
\text { pengetahuan. } \\
\text { 4. Kemampuan menganalisis } \\
\text { pekerjaan. } \\
\text { 5. Pemahaman yang baik tentang } \\
\text { pekerjaan. }\end{array}$ & Skala Likert 1-5 & $\begin{array}{l}\text { (Malayu, } \\
\text { 2008) }\end{array}$ \\
\hline $\begin{array}{c}\text { Literasi } \\
\text { Keuangan }\end{array}$ & & $\begin{array}{l}\text { 1. Pendapatan } \\
\text { 2. Pengeluaran (spending literation). } \\
\text { 3. Literasi tentang kredit (credit } \\
\text { literation). } \\
\text { 4. Literasi tentang tabungan (saving } \\
\text { literation). } \\
\text { 5. Literasi tentang investasi } \\
\text { (investment literation). }\end{array}$ & Skala Likert 1-5 & $\begin{array}{l}\text { Huston } \\
(2010), \\
\text { Remund } \\
(2010)\end{array}$ \\
\hline $\begin{array}{c}\text { Perencanaan } \\
\text { Keuangan }\end{array}$ & $\begin{array}{l}\text { Perencanaan } \\
\text { keuangan adalah } \\
\text { tujuan hidup } \\
\text { seseorang yang } \\
\text { dilakukan melalui } \\
\text { sebuah perenca- } \\
\text { naan keuangan } \\
\text { yang disusun } \\
\text { sehingga terben- } \\
\text { tuk tujuan jangka } \\
\text { pendek dan jangka } \\
\text { panjang. }\end{array}$ & $\begin{array}{l}\text { 1. Pelaku usaha memiliki tujuan } \\
\text { jangka pendek. } \\
\text { 2. Pelaku usaha memiliki usaha } \\
\text { jangka menengah. } \\
\text { 3. Pelaku usaha memiliki usaha } \\
\text { jangka panjang. } \\
\text { 4. Pelaku usaha memiliki perencanaan } \\
\text { keuangan dapat terbentuk mulai } \\
\text { dari pendapatan. } \\
\text { 5. Pelaku usaha memiliki perencanaan } \\
\text { pengeluaran yang jelas. } \\
\text { 6. Pelaku usaha telah melakukan } \\
\text { tabungan dan investasi. }\end{array}$ & Skala Likert 1-5 & $\begin{array}{l}\text { FPSB } \\
\text { (2007) }\end{array}$ \\
\hline $\begin{array}{c}\text { Perilaku } \\
\text { Keuangan }\end{array}$ & $\begin{array}{l}\text { Perilaku mem- } \\
\text { berikan perspektif } \\
\text { perilaku keuangan } \\
\text { dari proses pen- } \\
\text { gambilan keputu- } \\
\text { san. }\end{array}$ & $\begin{array}{l}\text { 1. Kecendrungan mempertimbangkan } \\
\text { pendapatan dan pengeluaran. } \\
\text { 2. Pengambilan keputusan keuangan. } \\
\text { 3. Sifat keputusan dan lingkungan } \\
\text { membuat pengaruh jenis proses } \\
\text { yang digunakan. } \\
\text { 4. Pengambil keputusan keuangan } \\
\text { secara neurologis cenderung untuk } \\
\text { mempengaruhi (emosi). } \\
\text { 5. Perilaku keuangan memperhatikan } \\
\text { prinsip-prinsip kepentingan pribadi } \\
\text { sempurna, rasionalitas yang } \\
\text { sempurna, dan informasi yang } \\
\text { sempurna mengatur keputusan } \\
\text { ekonomi individu. }\end{array}$ & Skala Likert 1-5 & $\begin{array}{l}\text { Olson } \\
\text { (2001) }\end{array}$ \\
\hline
\end{tabular}


Hasil uji hipotesis tampak pada tabel berikut.

Tabel 2. Hasil Uji Hipotesis

\begin{tabular}{lccc}
\hline & $\beta$ & $\alpha$ & Hasil \\
\hline $\begin{array}{l}\text { H1: Tingkat Pendidikan berpengaruh positif dan signifikan } \\
\text { terhadap perilaku keuangan UMKM }\end{array}$ & 0.157 & 0,007 & Diterima \\
\hline $\begin{array}{l}\text { H2: Literasi keuangan berpengaruh positif dan signifikan ter- } \\
\text { hadap perilaku keuangan UMKM }\end{array}$ & 0,108 & 0,034 & Diterima \\
\hline $\begin{array}{l}\text { H3: Perencanaan Keuangan berpengaruh positif dan signifi- } \\
\text { kan terhadap perilaku keuangan UMKM }\end{array}$ & 0,183 & $\bullet, 000$ & Diterima \\
\hline
\end{tabular}

\section{Pengaruh Tingkat Pendidikan terhadap Perilaku Keuangan}

Hipotesis satu dalam penelitian ini adalah tingkat pendidikan berpengaruh positif dan signifikan terhadap perilaku keuangan UMKM. Hasil penelitian ini menunjukkan bahwa tingkat pendidikan berpengaruh positif terhadap perilaku keuangan UMKM ( $\boldsymbol{\beta}=0.157 ; \boldsymbol{\alpha}=0,007)$. Jadi H1 diterima. Hasil penelitian ini mendukung penelitianpenelitian sebelumnya yang menyatakan tingkat pendidikan memiliki peran yang sangat penting untuk memiliki kemampuan memahami, menilai, dan bertindak dalam kepentingan keuangan pelaku usaha terutama pada pendidikan keuangan (Jhonson, 2007). Selanjutnya dalam penelitian yang dilakukan Gutter (2008) menyatakan bahwa pendidikan keuangan berpengaruh positif signifikan terhadap perilaku dan pengetahuan keuangan.

\section{Pengaruh Literasi Keuangan terhadap Perilaku Keuangan}

Hipotesis kedua dalam penelitian ini adalah literasi keuangan berpengaruh positif dan signifikan terhadap perilaku keuangan UMKM. Hasil penelitian ini menunjukkan bahwa literasi keuangan berpengaruh positif terhadap perilaku keuangan UMKM ( $\beta$ $=0.108 ; \boldsymbol{\alpha}=0,034)$. Jadi H2 diterima. Literasi keuangan dalam hal ini tidak hanya dilihat dari segi kognitif yang melibatkan pengetahuan dan kemampuan untuk menangani masalah keuangan namun kemampuan dalam literasi keuangan dilihat dari aspek nonkognitif.
Sehingga aspek tersebut dilihat dari aspek psikologis seseorang yang berkaitan dengan permasalahan kuangan yang terjadi (PISA, 2012).

\section{Pengaruh Perencanaan Keuangan terhadap Perilaku Keuangan}

Hipotesis ketiga dalam penelitian ini adalah perencanaan keuangan berpengaruh positif dan signifikan terhadap perilaku keuangan UMKM. Hasil penelitian ini menunjukkan bahwa perencanaan keuangan berpengaruh positif terhadap perilaku keuangan UMKM $(\boldsymbol{\beta}=0.183 ; \boldsymbol{\alpha}=0,000)$. Jadi H3 diterima. Perencanaan keuangan sangat penting untuk pelaku usaha dalam sebuah UMKM karena menentukan tujuan jangka pendek, jangka menengah dan jangka panjang. Perencanaan keuangan telah terbukti memiliki dampak yang signifikan terhadap manajemen keuangan, dan lebih konsisten ketika berbagai macam kebijakan digunakan (Sarah, 2009). Pelaku usaha kecil menengah akan mampu melakukan pengelolaan keuangan usahanya dan pengelolaan yang sesuai adalah akan menjadi faktor utama terhadap kepuasan keuangan atau ketidakpuasan keuangan seseorang. Secara teoritis, pengetahuan keuangan tentang bagaimana pasar keuangan beroperasi harus menghasilkan individu yang membuat keputusan lebih efektif (Robb dan Woodyard, 2011). 


\section{SIMPULAN DAN SARAN}

berikut:

Simpulan dari penelitian adalah sebagai

1. Tingkat pendidikan berpengaruh positif dan signifikan terhadap perilaku keuangan UMKM. Dimensi yang berpengaruh pada penelitian ini adalah latar belakang pendidikan sesuai; kemampuan menganalisis pekerjaan sesuai dengan latar pendidikan; usaha yang dimiliki sesuai dengan pengetahuan yang dimiliki; kemampuan menganalisis pekerjaan; dan pemahaman yang baik tentang pekerjaan.

2. Literasi keuangan berpengaruh positif dan signifikan terhadap perilaku keuangan UMKM. Dimensi yang berpengaruh adalah pendapatan, pengeluaran (spending literation), literasi tentang kredit (credit literation), literasi tentang tabungan (saving literation), dan literasi tentang investasi (investment literation).

3. Perencanaan keuangan berpengaruh positif dan signifikan terhadap perilaku keuangan UKM. Dimensi yang berpengaruh dalam perencanaan keuangan adalah pelaku usaha memiliki tujuan jangka pendek, pelaku usaha memiliki usaha jangka menengah, pelaku usaha memiliki usaha jangka panjang, pelaku usaha memiliki perencanaan keuangan dapat terbentuk mulai dari pendapatan, pelaku usaha memiliki perencanaan pengeluaran yang jelas, pelaku usaha telah melakukan tabungan, dan investasi.

Implikasi manajerial dari hasil penelitian ini adalah perlunya menumbuhkan literasi keuangan yang diharapkan memberi dampak pada perilaku keuangan, dengan cara:

1. Untuk meningkatkan literasi keuangan yang berpengaruh pada perilaku keuangan maka pelaku usaha khususnya UMKM mengikuti pelatihan-pelatihan atau kursus singkat mengenai pengetahuan tentang keuangan dan manajemen usaha kecil menengah.

2. Peningkatan literasi keuangan dalam pengelolaan keuangan UMKM yaitu dengan melakukan perencanaan keuangan yang memperhatikan berbagai aspek yaitu pelaku usaha memiliki perencanaan keuangan baik dari sisi pendapatan maupun pengeluaran dengan jelas, memiliki tabungan dan investasi, agar mudah dalam pengajuan permohonan kredit ke lembaga keuangan.

Penelitian ini memiliki keterbatasan, antara lain penelitian ini hanya dilakukan pada tingkat usaha kecil dan menengah dan tidak mempertimbangkan local wisdom. Untuk itu pada penelitian selanjutnya peneliti merekomendasikan beberapa hal yang bisa dilakukan antara lain: memperluas wilayah penelitian, misalnya area Jawa Tengah, memperluas variabel penelitian seperti pengetahuan keuangan, tingkat kepuasan keuangan, sikap keuangan, pengambilan keputusan investasi, dalam rangka mengambangkan UMKM.

\section{REFERENSI}

ACCA. 2014. Financial Education for Entrepreneurs: What Next? Retrieved from: http://www.accagloba;.com/ content/dam/acca/global/PDFtechnical/small-business/pol-tp-fefe. pdf.

Agarwal, S. J. 2008. Optimal Mortgage Refinancing: A Closed Form Solution. NBER Working.

Agarwal, S. J. 2009. The Age of Reason: Financial Decisions over the Life-Cycle and Implications for 
Regulation. Brookings Papers on Economic Activity. Vol.2, 51-117.

Agarwal, S. P. 2009. Payday Locansand Credit Cards: New Liquidity and Credit Scoring Puzzles?'. American Review. Vol.99 (2), 412-417.

Almenberg, J., dan Soderbergh, J.S. 2011. Financial Literacy and Retirement Planning in Sweden, Journal of Pension Economics and Finance. 10 (4), 585-598

Almenberg, J. a. 2012. Ecponential Growth Bias and Financial Literacy. Applied Economics Letters. Vol 19 , 16931696.

Atkitson, A. M. 2012. Measuring Financial. Paris: Internasional Network on Financial Education (INFE) Pilot Study. OECD Working Papers on Finance, Insurance and Private Pensions.

Beckket, A. P. 1998. An Exposition of Consumer Behaviour in The Financial Services Review. Bank Mark. Vol 18, 15-26.

Chen, H. V. 1998. An Analysis of Personal Finance Literay Among College Students. Financial Services Review. Vol 7, 107-128.

E. T. Marihot, Hariandja. 2002. Manajemen Sumber Daya Manusia. Jakarta: Grasindo.

Financial Planning Standards Board (FPSB). 2007. Fundamental of Financial Planning. Jakarta: CFP.

Fuad, Ihsan. 2005. Dasar-dasar Pendidikan. Jakarta: PT. Asi Mahasatya.

Gerardi, K. L. 2010. Financial Literacy and Subprime Mortgage Delinquency: Evidence From a Survey Matched to Administrative Data. Federal Reserve Bank Atlanta . 10.

Gitman, Lawrence J. 2002. Principles of
Manajerial Finance. International Edition. $10^{\text {th }}$ edition. Pearson Education Boston.

Gutter, E. A. 2008. Financial Management Practise of College Student from States with Varying Financial Education Manadates. India.

Huston, S. 2010. Measuring Financial Literacy. Consumer Affairs. Vol. 44, Issue 2.

Indonesia, F. P. 2013. Fundamental of Financial Planning. Jakarta: FPSB Indonesia.

Johnson, Richard. 2007. Applied Multivariate Statistical Analysis. Prentice Hall. United States of America.

Lennox. 2014. It's Time to Bridge the Entrepreneur Financial Literacy Gap. http://business. financialpost/2014/04/25/itstime-tobridge-the-entrepreneur-financialliteracy-gap/?

Lusardi,A.2004. Saving and TheEffectiveness of Financial Educations. Financial Transformation. Vol. 15, 157-184.

Lusardi, A. 2006a. Baby Boomer Retirement Security: The Roles of Planning Financial Literacy and Housing Wealth. Journal of Monetary Economics, 54, 205-224.

Lusardi, A., Mitchell, O.S. 2006. Financial Literacy and Planning: Implications for Retirement Wellbeing.

Lusardi, A. 2006b. Financial Literacy and Palnning: Implication for Retirement Wellbeing. Pension Reseacrh Council Working Paper .

Lusardi, Annamaria \& Olivia Mitchel. 2007. Financial Literacy and Retirement Planning: New Evidence from the Rand American Life Pannel.

Lusardi, A. 2007b. Financial Literacy and Retirement Planning: New Evidence 
from The Rand American Life Panel. Michigan Retirement Reseacrh Center, 157.

Lusardi, A. O. 2009. Financial Literacy Among The Young: Evidence and Implications for Consumer Policy. Philadelphia: The Pension Research Council.

Lusardi, Annamaria \& Peter Tufano. 2009. Debt Literacy, Financial Experience, and overindebtedness. NBER Working Paper. No. 14808

Lusardi, Annamaria. 2010. Financial Literacy among The Young: Evidence and Implication for Consumer Policy

Lusardi, Annamaria, and Olivia S. Mitchell. 2011. "Financial Literacy and Planning: Implications for Retirement Wellbeing," In Financial Literacy: Implications for Retirement Security and the Financial Marketplace. Eds A Lusardi and O.S. Mitchell . Oxford: Oxford University Press forthcoming

Lusardi, A. 2014. The Economic Importance of Financial Literacy: Theory and Evidence. Journal of Economic Literature. Vol. 1, 5-44.

Marcolin, S. A. 2006. Financial Literacy Reseacrh: Current Literature and Future Opportunities. Procediings of the 3rd International Conference on Contempory Business. Charles Sturt University.

Mitchell, O. 1998. Worker Knowledge of Pensions Provisions. Journal of Labor Economics Vol. 6, 21-39.

OECD. 2012. Measuring Financial Literacy: Results of the OECD/International Network on Financial Education (INFE) Pilot Study. OECD Working Papers on Finance, Insurance and Private Pensions, 15.

OECD. 2014. Progress Report on Financial Education. http://www.oecd.org/
finance/financial-education/OECDINFE-FinEd-G20-2014-ProgressReport.pdf.

Olson, J. 2001. Tolerance of Personal Deprivation. Emerging Prespectives on Ideology, Justice and Intergroup Relations.

PISA. 2012. Financial Literacy Assessment Framework. http://www.oecd.org/ pisa/ pisaproducts/46962580.pdf.

Pompian, M. M. 2006. Behavioral Finance and Wealth Management. Canada, New Jersey: Hoboken.

Remund, D. 2010. Financial Literacy Explicated: The Case for a Clear Definition in an Increasingly Complex Economy. The Journal of Consumer Affairs. Vol. 8, 170-184.

Robb, C.A. and James, R.N. 2009. Assosiation between Individual Characteristics and Financial Knowledge. Journal of Personal Finance. Vol. 8, 170-184.

Robb, C. A., \& Woodyard, A. S. 2011. Finanacial Knowledge and Best Practice Behaviour. Journal of Financial Counseling and Planning. Vol. 22, Issue 1.

Roberts, J. E. 2001. Money Attitudes, Credit Card Use and Compulsive Buying. Among American College Students. Vol. 2, 213-240.

Sabri, M. 2011. Pathways to Financial Sucess: Determinants of Financial Literacy and Financial Well-Being Among Young Adults.

Sarah, Nannyanzi. 2009. Financial Knowledge, Locus Of Control, Culturalvalues and Financial Behaviour Among New Vision Employees. Thesis. University Kampala

Sikula. E. Andrew. 2011. Manajemen Sumber Daya Manusia. Bandung: Erlangga. 
Sugiyono. 2010. Metode Penelitian Pendidikan Pendekatan Kuantitatif, Kualitatif, dan R\&D. Bandung: Alfabeta

Sulo. Tirtahardjo. 2005. Pengantar Pendidikan. Bandung: Rinema Cipta.

Van Rooij, M. A. 2007. Financial Literacy and Stock Market Participation. Michigan Retirement Research Center Paper, 162.
Van Rooij, M., Lusardi, A., Alessie, R. 2011. Financial Literacy and Retirement Planning in the Netherlands. Elsevier. 32. 593-608.

Widayati, Irin. 2012. Faktor-Faktor yang Mempengaruhi Literasi Finansial Mahasiswa Fakultas Ekonomi dan Bisnis Universitas Brawijaya. ASSET: Jurnal Akuntansi dan Pendidikan, Vol.1, No. 1. 